\title{
ELECTROPHORETIC CHANGES IN THE PLASMA PROTEIN PATTERNS OF PATIENTS WITH RELAPSING MALARIA ${ }^{1}$
}

\author{
By VINCENT P. DOLE 2 AND KENDALL EMERSON, JR.,2 \\ WITH THE TECHNICAL ASSISTANCE OF ESTHER BRAUN \\ (From the United States Navy Research Unit at the Hospital of The Rockefeller \\ Institute for Medical Research, New York)
}

(Received for publication January 30, 1945)

Numerous studies of the serum or plasma proteins in malaria have shown that there is a depression of albumin and a relative rise of globulins following paroxysms. Two workers (1), from a review of the earlier literature and from experimental studies with monkey malaria, concluded that, while the changes were not specific for malaria, the amount of change generally correlated with the intensity of an attack. In the interval between relapses, the serum total protein and albumin: globulin values tended to return toward normal, an improvement that was accelerated by treatment. Later observations on human subjects (2 to 4) have also been in accord with these findings.

Although it has been suggested (5) that the increase in the serum fraction precipitable by 13.5 per cent sodium sulfate might be sufficiently characteristic of the disease to be the basis of a diagnostic test for malaria, the subsequent use of this test (6) indicated that similar increases would also be encountered in a variety of other diseases.

All previous studies have been made with some type of salt fractionation. The purpose of the present study was to supplement these earlier observations by electrophoretic analyses, and to ascertain whether or not any test based upon changes in the plasma protein pattern might be of diagnostic use in the group of patients with relapsing malaria.

\section{PROCEDURE}

The 8 subjects studied were admitted because of malarial relapses. All had first been exposed to infection about 12 months prior to admission. In the intervening period they had had a variable number of relapses (2 to 12) but no complications. Their nutritional status was

1 The Bureau of Medicine and Surgery does not necessarily undertake to endorse views or opinions which are expressed in this paper.

2 Lieutenant Commander, Medical Corps, United States Naval Reserve. good owing to the prompt medical attention that they had received for each relapse. Records of earlier attacks indicated that several of the patients at least had originally had mixed infections ( $P$. vivax and $P$. falciparum) but at the time of these studies the falciparum parasites had apparently disappeared as only vivax forms were found in numerous blood smears. While the group is restricted rather than representative of more extreme cases of the disease, the subjects are typical of the otherwise healthy patients in whom it is desired to recognize latent infection prior to a relapse.

Each of the 8 patients was allowed to have 3 paroxysms, which were tolerated without undue discomfort. At the time of the third paroxysm, the course of the disease was interrupted with atabrine or quinine therapy in all but 1 patient (Sch.). This patient spontaneously arrested his paroxysms after the second. On the morning following admission a fasting blood sample was taken for determinations of the plasma protein concentration by the Kjeldahl method, the albumin: globulin ratio by salt fractionation, and for electrophoretic analysis by procedures previously described (7). Subsequent samples were taken at various times as indicated in Table $I$ and in Figure 1.

\section{RESULTS AND DISCUSSION}

Although the total protein concentrations remained within normal limits, the albumin: globulin ratios were found to be depressed both in the chemical and in the electrophoretic analyses, thus confirming reports in the literature. It is seen (Table I, Figure 1) that the globulin increase occurs principally in the fibrinogen and the $\gamma$ globulin fractions. The latter is of interest both because it probably carries antibody activity (8) and because it presumably is the main fraction precipitated from serum by 13.5 per cent sodium sulfate.

The significant fact, however, is that the pattern tends to return to normal despite persistent infection after the paroxysms are interrupted by treatment. Each of the patients of Figure 1 (Sp., Tr.) had a further relapse not due to reinfection with 2 months of discharge from the hospital. The abnormalities in protein pattern thus appear 
TABLE I

Plasma protein data from six malarial patients

Days are counted from the first paroxysm of the current relapse. The last 6 columns give the fractions of the total protein furnished by the components: Albumin, $\alpha_{1}, \alpha_{2}$, and $\beta$ globulins, fibrinogen, and $\gamma$ globulin. Note that the average includes data given graphically in Fig. 1. The normal values are from reference 7.

\begin{tabular}{|c|c|c|c|c|c|c|c|c|c|c|}
\hline \multirow{2}{*}{ Patient } & \multirow{2}{*}{ Day } & \multirow{2}{*}{$\begin{array}{l}\text { Total } \\
\text { protein }\end{array}$} & \multicolumn{2}{|c|}{ Albumin:Globulin } & \multirow{2}{*}{$\frac{\text { Alb. }}{T}$} & \multirow{2}{*}{$\frac{\alpha_{1}}{T}$} & \multirow{2}{*}{$\frac{\alpha 2}{T}$} & \multirow{2}{*}{$\frac{\beta}{T}$} & \multirow{2}{*}{$\frac{6}{T}$} & \multirow{2}{*}{$\frac{r}{T}$} \\
\hline & & & $\begin{array}{l}\text { Salt frac- } \\
\text { tionation }\end{array}$ & $\begin{array}{l}\text { Electro- } \\
\text { phoresis }\end{array}$ & & & & & & \\
\hline Sh (No. 11539) & $\begin{array}{r}7 \\
12 \\
21\end{array}$ & $\begin{array}{c}\text { grams per } \\
100 \mathrm{ml} \text {. } \\
6.71 \\
6.48 \\
6.42\end{array}$ & $\begin{array}{l}1.44 \\
1.17 \\
1.67\end{array}$ & $\begin{array}{l}1.00 \\
0.91 \\
1.22\end{array}$ & $\begin{array}{l}0.500 \\
0.477 \\
0.552\end{array}$ & $\begin{array}{l}0.052 \\
0.062 \\
0.042\end{array}$ & $\begin{array}{l}0.066 \\
0.070 \\
0.065\end{array}$ & $\begin{array}{l}0.152 \\
0.120 \\
0.129\end{array}$ & $\begin{array}{l}0.079 \\
0.096 \\
0.063\end{array}$ & $\begin{array}{l}0.151 \\
0.175 \\
0.149\end{array}$ \\
\hline $\operatorname{Ar}($ No. 11541) & $\begin{array}{l}1 \\
5\end{array}$ & $\begin{array}{l}6.67 \\
6.73\end{array}$ & $\begin{array}{l}2.06 \\
1.50\end{array}$ & $\begin{array}{l}1.13 \\
0.96\end{array}$ & $\begin{array}{l}0.530 \\
0.490\end{array}$ & $\begin{array}{l}0.059 \\
0.057\end{array}$ & $\begin{array}{l}0.088 \\
0.067\end{array}$ & $\begin{array}{l}0.144 \\
0.152\end{array}$ & $\begin{array}{l}0.068 \\
0.076\end{array}$ & $\begin{array}{l}0.111 \\
0.158\end{array}$ \\
\hline Sch (No. 11534) & $\begin{array}{r}6 \\
27\end{array}$ & $\begin{array}{l}6.30 \\
6.51\end{array}$ & $\begin{array}{l}1.72 \\
2.56\end{array}$ & $\begin{array}{l}1.07 \\
1.27\end{array}$ & $\begin{array}{l}0.517 \\
0.559\end{array}$ & $\begin{array}{l}0.056 \\
0.043\end{array}$ & $\begin{array}{l}0.067 \\
0.107\end{array}$ & $\begin{array}{l}0.149 \\
0.113\end{array}$ & $\begin{array}{l}0.077 \\
0.057\end{array}$ & $\begin{array}{l}0.134 \\
0.121\end{array}$ \\
\hline Mu (No. 11554) & $\begin{array}{r}4 \\
11\end{array}$ & $\overline{6.33}$ & $\overline{1.92}$ & $\begin{array}{l}0.81 \\
1.13\end{array}$ & $\begin{array}{l}0.448 \\
0.531\end{array}$ & $\begin{array}{l}0.072 \\
0.052\end{array}$ & $\begin{array}{l}0.145 \\
0.111\end{array}$ & $\begin{array}{l}0.152 \\
0.143\end{array}$ & $\begin{array}{l}0.096 \\
0.063\end{array}$ & $\begin{array}{l}0.087 \\
0.100\end{array}$ \\
\hline Ma (No. 11549) & 35 & 6.30 & 1.24 & 0.95 & 0.487 & 0.048 & 0.045 & 0.131 & 0.063 & 0.226 \\
\hline $\mathrm{Pa}$ (No. 11529) & 7 & 6.40 & 2.01 & 1.30 & 0.566 & 0.036 & 0.085 & 0.133 & 0.052 & 0.128 \\
\hline $\begin{array}{l}\text { Average (including } \\
\text { Sp., Tr.) }\end{array}$ & & 6.88 & 1.73 & 1.07 & 0.514 & 0.051 & 0.083 & 0.132 & 0.074 & 0.145 \\
\hline Normal values & & 6.70 & 2.2 & $\begin{array}{c}1.53 \\
( \pm 0.18)\end{array}$ & $\begin{array}{c}0.603 \\
( \pm 0.028)\end{array}$ & $\begin{array}{r}0.046 \\
( \pm 0.007)\end{array}$ & $\begin{array}{c}0.072 \\
( \pm 0.013)\end{array}$ & $\begin{array}{r}0.121 \\
( \pm 0.019)\end{array}$ & $\begin{array}{c}0.051 \\
( \pm 0.006)\end{array}$ & $\begin{array}{r}0.110 \\
( \pm 0.025)\end{array}$ \\
\hline
\end{tabular}

to be due to host reaction to the acute process of a paroxysm rather than to the mere presence of parasites in the body. Moreover, the non-specific nature of the $\gamma$ globulin rise is attested by the increase of this component after streptococcal infections as described in the following paper.

The average mobilities of plasma protein components were within normal limits in the malarial plasmas (Table II), indicating that there was no detectable amount of protein with unusual mobility.

In more severe forms of malaria, an extreme depression of albumin concentration may occur, as shown by the data of Table III. This patient, ${ }^{3}$ not included in the averages of Tables I and II,

s Seen through the courtesy of Dr. Harry Most. was a woman, age 22 , who came under medical observation only after having suffered severe untreated $P$. falciparum malaria for 3 weeks. The apparent increase in mobilities of all components is probably due merely to the greater dilution of proteins.

It appears necessary to conclude that methods based on changes in relative concentrations of the plasma protein components are of no diagnostic value, both because the changes that do occur are non-specific and because the pattern tends to return to normal despite persistent infection. It is, however, probable that determinations of the total protein concentration and of the albumin:globulin ratio would be useful adjuncts in evaluating the severity of the disease.

TABLE II

Mobilities $\times 10^{5}$ (cm.2 per oolt second) of the plasma protein components in malarial and normal plasma. Averages and standard deviations are computed from 15 normal (7) and 23 malarial plasmas

\begin{tabular}{l|c|c|c|c|c|c}
\hline \hline & Albumin & $\alpha_{1}$ & $\alpha_{2}$ & $\phi$ & $\phi$ & $\gamma$ \\
\hline Malaria & $5.89 \pm 0.277$ & $4.99 \pm 0.264$ & $4.00 \pm 0.276$ & $3.03 \pm 0.250$ & $2.15 \pm 0.168$ & $1.18 \pm 0.142$ \\
Normal & $5.94 \pm 0.267$ & $5.07 \pm 0.236$ & $4.08 \pm 0.256$ & $2.83 \pm 0.241$ & $2.14 \pm 0.252$ & $1.02 \pm 0.282$ \\
\hline
\end{tabular}




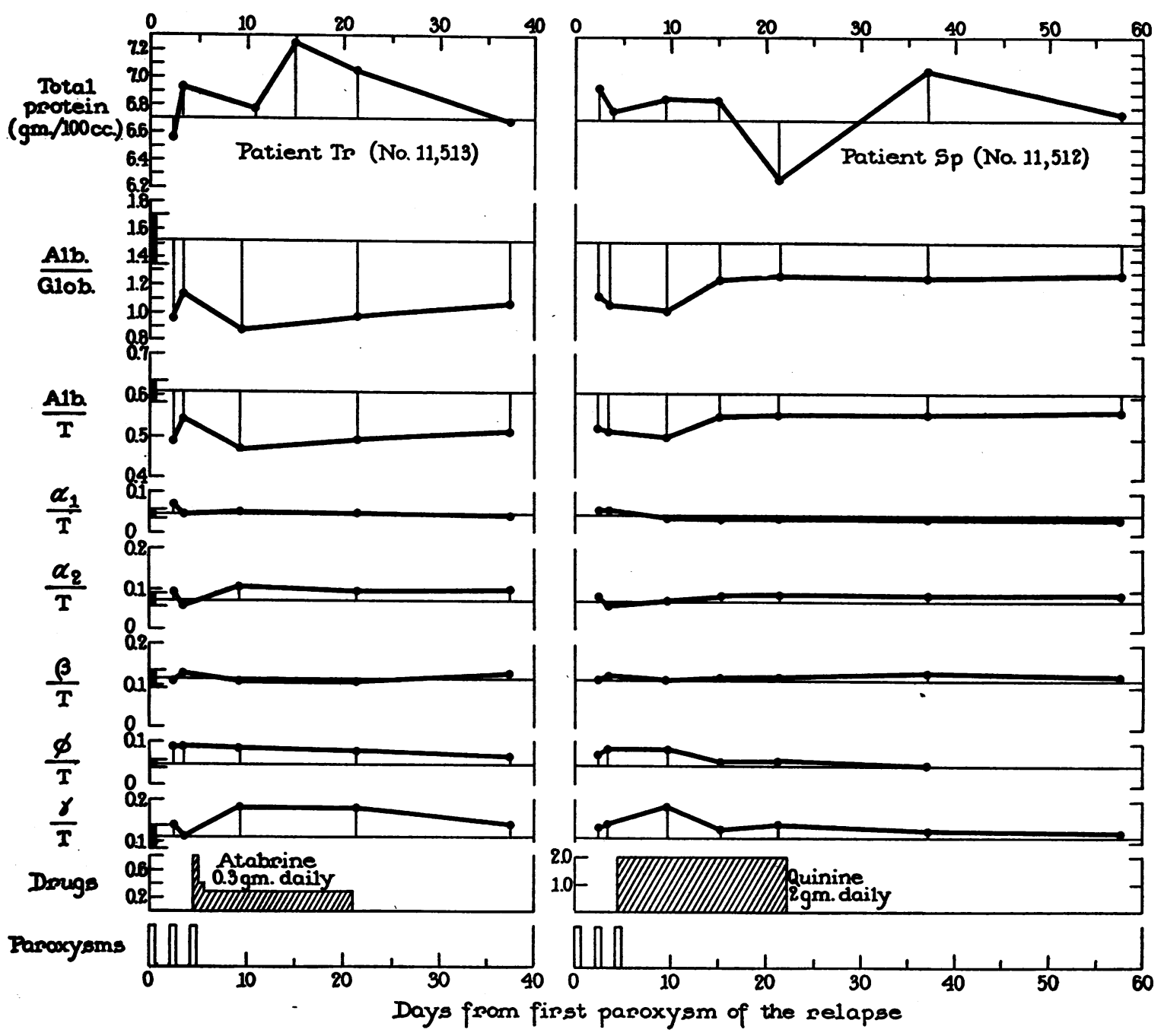

Fig. 1. Time Changes in the Electrophoretic Plasma Patterns of 2 Patients

Shown on the ordinates are the total protein concentration, the electrophoretic albumin: globulin ratio, and the ratios to total protein concentration (T) of albumin and of the globulins $\left(\alpha_{1}, \alpha_{2}, \beta, \phi, \gamma\right)$, where $\phi$ denotes fibrinogen. Normal average values for these are given by the light horizontal lines, while normal ranges (of 1 standard deviation) are shown by the heavy brackets at the left. Note that the ordinate scales for drug dosage differ in the 2 cases, although the units (grams per day) are the same.

TABLE III

Data obtained from 1 patient with severe untreated $P$. falciparum malaria

\begin{tabular}{|c|c|c|c|c|c|c|c|c|c|}
\hline & \multirow{2}{*}{$\begin{array}{c}\text { Total } \\
\text { protein }\end{array}$} & \multicolumn{2}{|c|}{ Albumin:Globulin } & \multirow{2}{*}{$\frac{\text { Alb. }}{T}$} & \multirow{2}{*}{$\frac{\alpha_{1}}{T}$} & \multirow{2}{*}{$\frac{\alpha_{2}}{T}$} & \multirow{2}{*}{$\frac{\beta}{T}$} & \multirow{2}{*}{$\frac{\phi}{T}$} & \multirow{2}{*}{$\frac{r}{T}$} \\
\hline & & $\begin{array}{l}\text { Salt frac- } \\
\text { tionation }\end{array}$ & $\begin{array}{l}\text { Electro- } \\
\text { phoresis }\end{array}$ & & & & & & \\
\hline Concentrations & $\begin{array}{c}\text { grams per } \\
100 \mathrm{ml} \text {. } \\
3.64\end{array}$ & 1.30 & 0.72 & 0.417 & 0.089 & 0.086 & 0.163 & 0.095 & 0.147 \\
\hline \multicolumn{3}{|c|}{ Mobilities $\times 10^{5}\left(\mathrm{~cm} .{ }^{2}\right.$ per volt second $)$} & & 6.34 & 5.39 & 4.47 & 3.18 & 2.28 & 1.20 \\
\hline
\end{tabular}


SUM MARY

1. Eight patients with relapsing $P$. vivax malaria were found to have normal total protein concentrations, but depression in albumin and increases in the globulins, notably fibrinogen and $\gamma$ globulin.

2. In the 2 of these patients that were studied by repeated electrophoretic analyses, the plasma patterns tended during subsequent weeks to return to normal, despite persistent infection as proven by later relapses.

3. The 1 patient with severe $P$. falciparum malaria was found to have an extreme depression of total protein concentration, due mainly to reduction in albumin.

4. It is concluded that the changes in the plasma protein pattern are of no diagnostic value, but that measurement of the total protein concentration and the albumin:globulin ratio may be of aid in evaluating the severity of the disease.

The authors are indebted to Drs. T. Shedlovsky and D. A. MacInnes for their generosity in making available the electrophoretic equipment used in this study.

\section{BIBLIOGRAPHY}

1. Ghosh, B. N., and Sinton, J. N., Quantitative changes in the proteins of the blood sera of monkeys infected with malarial plasmodia. Rec. Malaria Survey India, 1935, 5, 173.

2. Chopra, R. N., Mukherjee, S. N., and Sen, B., Studies on the protein fractions of blood sera. Part III : Malarial sera during and after the rigor stage. Indian J. M. Research, 1935, 22, 571.

3. Boyd, M. F., and Proske, H. O., Observations on the blood proteins during malaria infections. Am. J. Trop. Med., 1941, 21, 245.

4. Kopp, I., and Solomon, H. C., The relationship of hypoalbuminemia to the edema of malaria. Am. J. M. Sc., 1941, 202, 861.

5. Proske, H. O., and Watson, R. B., The protein tyrosin reaction. A biochemical diagnostic test for malaria. Pub. Health Rep., 1939, 54, 158.

6. Swartzwelder, J. C., and Adams, C. C., Studies on the protein tyrosine reaction as a diagnostic test for malaria. Am. J. Trop. Med., 1941, 21, 717.

7. Dole, V. P., The electrophoretic patterns of normal plasma. J. Clin. Invest., 1944, 23, 708.

8. Enders, J. F., The concentrations of certain antibodies in globulin fractions derived from human blood plasma. J. Clin. Invest., 1944, 23, 510. 